\title{
THE CONCEPT OF TEACHER TRAINING CO-FINANCED BY THE EUROPEAN UNION IN THE TEACHER TRAINING SCHOOL MODEL
}

\author{
Monika KLEMKE-PITEK \\ UTP University of Science and Technology in Bydgoszcz; Faculty of Management, Department of Innovative \\ Organization Management; monika.kp@utp.edu.pl, ORCID: 0000-0001-8489-0247
}

Purpose: The aim of the article is to present the concept of training directed at teachers in the Teacher Training School model.

Design/methodology/approach: The article presents the assumptions of the Teacher Training School as a modern system of supporting teachers' competences. The possibilities of co-financing the establishment and running of training schools in Poland under the Human Capital Operational Programme 2014-2020 were presented. The training offer for teachers was discussed and characterized in an exemplary project co-financed by the European Union: "Teacher Training School model in Niemcz and Osielsko" based on the expectations of teachers in the light of the pilot studies conducted on a sample of 52 people. Finally, recommendations for the organization of the training process for teachers were indicated.

Findings: The article presents the assumptions of the Teacher Training School as a modern system of supporting teachers' competences.

Research limitations/implications: Assessment of the effectiveness of the created teacher training school on other schools, with the use of integrated resources of local institutions established to support the work of the training school, will be possible only after the completion of the project.

Practical implications: The planned evaluations of 42 training schools established in Poland will allow to verify long-term effects, including the effectiveness, relevance and durability of the changes introduced in the process of professional development and teacher education.

Social implications: The priority of educational policy in Poland is to ensure an effective system of education and continuous professional development of teachers which will respond to real needs of a school and will allow teachers to improve their professional competences and develop their workshop. The implementation of the Teacher Training School Model in Poland will have a social dimension directly affecting teachers' and indirectly pupils' key competences. Originality/value Based on the results of the pilot studies, satisfactory conclusions for the needs of teacher education in EU projects were drawn.

Keywords: training, development, teachers, competences, project, European Union. 


\section{Introduction}

Professional training of teachers is an integral part of the education system which significantly affects the quality of a teaching process. This is particularly important as teachers' high competences are correlated with students' learning outcomes. Professional development is a process of increasing employee qualifications, the knowledge of which must be constantly supplemented, developed and modernized at the workplace (Wysocka, Hajdukiewicz, 2016, p. 2). Many researchers emphasize that the improvement of employees' workshop will serve to strengthen their competences more if it is of practical nature, based on observation and exchange of experiences among teachers. The research results clearly show that high efficiency is built by a teacher not only through participation in training, but also through cooperation with other teachers and the opportunity to participate in joint projects at school. In Polish schools, however, such activities are rarely undertaken on the school premises (Hernik, Malinowska, Piwowarski, 2013, p. 5).

The priority of educational policy in Poland is to ensure an effective system of education and continuous professional development of teachers which will respond to real needs of a school and will allow teachers to improve their professional competences and develop their workshop. Schools, as well as teacher training institutions, should develop towards learning organizations, and by undergoing permanent evaluation, improve their development (Hajdukiewicz, Wysocka, 2016, p. 7). At the same time, it is important to promote the selfeducation system of teachers (Fila, Matuszczak, Rybińska, 2015, p. 43), and the principals of these institutions should play a key role in education (Fischer, Taylor, 2012, p. 235; Kordziński, 2010, p. 10).

The possibility of co-financing the teacher education system from EU funds allowed the commencement of work on a new model of improving and raising competences by teachers. Work in this area was carried out by the Ministry of National Education in Warsaw as part of the project: "Supporting the creation of training schools" implemented by the Education Development Centre (ORE) in 2016-2018. The developed concept was tested during a 10-month pilot project (in 2017-2018) which allowed the formulation of conclusions and recommendations for the creation of Teacher Training Schools in Poland (www.ore.edu.pl). 


\section{Assumptions of the Teacher Training School}

The Teacher Training School according to the model is: "a set of planned activities of schools (training schools and cooperating schools) and institutions supporting the learning process of teachers and students (...), "a school where future teachers will experience practical verification of the theory learned during their studies, and working teachers can improve their work techniques in cooperation with other teachers (...), "in the training school, a student under the guidance of a teacher will face educational practice in the areas of education and upbringing, and teachers will develop their workshop and share their ideas with other teachers" (Model szkoły ćwiczeń, 2019, p. 4).

The training school must take into account the cooperation and effective use of specialists and institutional resources from the local education environment:

- leading authorities (local governments),

- support centers (psychological and pedagogical counseling center, pedagogical library, teacher training center),

- universities (teaching schools).

Systematic cooperation of the institution with the training school is crucial for its development because the involvement of experts and resources will allow, on the one hand, to build the potential of the training school, and on the other - to popularize its achievements in the local environment (Zasady współpracy szkoły ćwiczeń, 2019, p. 2).

The education support system constructed in this way will be consistent with the directions of education policy, conclusions from pedagogical supervision, local education strategies and will respond to the needs of teachers from supported schools. The organization of the support system depends on the involvement of the leading authorities because local governments together with teacher training institutions, pedagogical libraries and psychological and pedagogical counseling centres should initiate cooperation and strategically plan joint activities for the development of local education (Gocłowska, Soćko, 2015, p. 43).

The model training school is to be a place for disseminating innovative activities supporting the development of students' key competences with particular emphasis on teaching foreign languages, mathematics, natural sciences, information and communication technologies and sharing knowledge and skills by teachers. At the same time, the training school should actively cooperate with other schools, support institutions and universities. In the scope of activities supporting the development of students' key competences the principals and teachers of the training school are obliged to promote and implement the use of innovative didactic, organizational and educational solutions in other schools. The training school should also be perceived as an institution implementing the local education strategy in terms of preparing the graduate to function on the labour market. 


\section{Possibilities of financing Model Teacher Training Schools from the European Union funds}

A chance to finance the establishment and operation of teacher training schools in Poland in accordance with the model concept developed by Education Development Centre (ORE) is the Knowledge Education Development Operational Programme (OP KED) for 2014-2020. EU projects may finance activities related to the preparation of schools for teacher training, established teacher training programmes, professional development, training for teachers of training schools in the field of methods and forms of didactic work (Szczegółowy Opis Osi Priorytetowych PO WER, 2019, p. 98-99).

The Ministry of National Education in Warsaw, as the Intermediate Body for Measure 2.10 "High quality of the education system" OP KED, announced in 2018-2019 two competitions under which the authorities managing schools could obtain funding for the creation and operation of training schools in accordance with the "Model szkoły ćwiczeń" established by the Education Development Centre (MEN, POWR.02.10.00-IP.02-00-005/18; MEN, POWR.02.10.00-IP.02-00-003/19).

Currently, 42 training schools across Poland are being created from the EU funds. They will carry out tasks in the field of professional development and teacher training and it is also planned to include each of these schools in the support process.

According to the competition regulations, activities that can be financed under the established training school (consisting of at least one and a maximum of four model schools), which will support at least seven cooperating schools are the following:

- diagnosis of the needs of supported schools which will be affected by the created training school,

- workshops for trainers (teachers) and teaching staff of training schools in the field of methods and forms of didactic work,

- conducting activities of the training school, including training and practical development for professionally active teachers in the field of developing key competences for students, practical training of students from pedagogical studies with the use of didactic and methodological materials supporting the professional development of teachers and practical preparation of students within training schools, evaluation of activities undertaken in order to verify the goals and determine the next possible actions.

In order to implement the above-mentioned assumptions in training schools for a particular school year, it is necessary for the school to conduct support for teachers of each of the 4 subject areas (foreign languages, mathematics, natural sciences, information and communication technologies): 
a) in the obligatory form:

- cooperation and self-education networks (at least 1 network for teachers of one subject area - at least for a period of 6 months, including at least 3 classroom meetings, 6 teaching hours each, and on-line work on the doskonaleniewsieci.pl platform),

- demonstration lessons (minimum 4 demo lessons for each subject area),

- methodological workshops (minimum 2 workshops - at least 6 didactic hours for each subject group),

b) in an optional form ( 2 forms to choose from):

- individual and collective consultations, supervision,

- student internships,

- conferences, seminars,

- discussion forums,

- blogs, other social media,

- development of teaching materials for teachers, students, internship supervisors in printed and multimedia forms (e.g. films, educational games).

\section{The concept of teacher training on the example of the Teacher Training School Model}

As part of the project "Teacher Training School Model in Niemcz and Osielsko", a number of activities have been planned that will lead to the achievement of the project objective: "Improving the functioning of the school support system in the development of key competences and universal skills on the labour market by preparing, supporting and jointly creating a training school by the Agata Mróz Primary School in Niemcz and the Polish Olympians Primary School in Osielsko, thanks to the implementation of comprehensive and complementary tasks: equipping classrooms in the training school (task 1), strengthening the competences of 52 school principals and teachers in the field of methods and forms of didactic work (task 2) and professional training of 62 school principals / teachers of supported schools in the field of conducting effective methods of work, developing key competences and universal skills of students (task 3 ) in the period from 01/01/2021 to 31/07/2022".

One of the tasks planned in the project is to strengthen the competences of school principals and teachers in the field of methods and forms of didactic work as part of workshop training. Teachers' competences must be strengthened because teachers as trainers of the training school will conduct demonstration lessons for students and teachers of supported schools. Thanks to the implementation of task 1 , demonstration lessons will take place in classrooms equipped accordingly to each of the 4 thematic areas: 
- mathematics area - 20 hours of demonstration lessons in maths,

- natural sciences area - 36 hours of demonstration lessons in the following subjects: natural sciences, biology, chemistry, physics, geography,

- the area of communication and educational technologies - 20 hours of IT demonstration lessons,

- language area - 20 hours of demonstration lessons in English and German.

In order to adjust the training process in the project to the needs and expectations of teachers (future trainers of the training school), a pilot study was carried out on a sample of 52 people potential trainers of the training school, using a questionnaire. The survey asked about the barriers faced by teachers who benefit from trainings, teachers' expectations regarding the organization of trainings and teachers' needs in terms of the content of trainings. In the last part of the questionnaire the surveyed teachers were asked to indicate the most important attributes (features) of a good training programme.

During the pilot studies teachers raised numerous concerns that should be overcome in the project. The most important barriers include:

- time barriers - reluctance to participate in direct forms of support due to the significant workload, hence the project should provide a support schedule in consultation with teachers, and most of the methods and forms of activity can be conducted online on the internet platform (www.doskonaleniewsieci.pl),

- financial barriers - insufficient financial resources for teachers' participation in professional development, hence the support in the project (training, materials, catering) must be free,

- mental barriers - teachers' reluctance to cooperate and share knowledge with other teachers and concerns about the low value of training, hence the integration of the teaching environment is planned, and training organizers must ensure a high level of education corresponding to the diagnosed training needs of teachers.

The expectations regarding the high substantive value of the training are confirmed by the research carried out by House of Skills which shows that the lecturer (trainer) plays a significant role in the training process. He should:

- have a charismatic personality (be open, warm, specific, determined, courageous, resourceful, aloof, professional to win the group's trust),

- have flexibility and the ability to adapt the content of education to the needs of recipients and their problems, take care of the appropriate pace of training and involvement of participants,

- have appropriate substantive knowledge and expert experience to be an authority for the participants. 
Potential participants of the training support had the following expectations towards the organization:

- short training forms (up to 6h),

- post-work training (after 2 p.m.),

- small training groups (up to 15 people),

- homogeneous groups consisted of teachers who teach similar subjects e.g. mathematicians, natural scientists, linguists.

The teachers' needs in terms of content discussed during trainings indicated the legitimacy of supporting seven issues in the amount of about 6 clock hours in the following topics:

- building innovative teaching programmes and lesson plans,

- creating one's own interactive teaching materials and making use of available materials on the web,

- the use of scientific experiment methods, experience and observations from life in education,

- the use of effective learning strategies according to students' sensory preferences, including the latest trends in motivating students to learn,

- shaping interpersonal and social skills of students - practical dimension (individual and group exercises, projects, games, simulations),

- the use of modern information and communication technologies, including support for modern ICT tools (interactive board, 3D printer, smartphone, tablet, computer clouds),

- online safety rules - cyberspace and cyber opportunities as well as ergonomics rules in the use of computer equipment.

According to teachers, the most important attributes (features) of good training are:

- teacher trainer - able to establish very good rapport with participants, creating a nice atmosphere, well prepared, being an authority in his field,

- training methodology - training conducted with the use of multimedia, activating methods of working with participants (experiments, exercises, discussions), valuable training materials at the end of the training,

- training content - training should give an opportunity to share knowledge and experiences with other participants, provide modern knowledge helpful in everyday work, theoretical knowledge should be supported by examples from life, training should encourage reflection and inspire further learning.

The above-mentioned features of good training are consistent with 17 attributes of training diagnosed in literature on the subject (Fazlagić, 2014), hence they may be helpful in preparation of training evaluation tools for teachers. 


\section{Summary}

Assessment of the effectiveness of the created teacher training school on other schools, with the use of integrated resources of local institutions established to support the work of the training school, will be possible only after the completion of the project. The planned evaluations of 42 training schools established in Poland will allow to verify long-term effects, including the effectiveness, relevance and durability of the changes introduced in the process of professional development and teacher education.

Based on the results of the pilot studies, the following conclusions were formulated for the needs of teacher education in EU projects:

- the schedule and hours of support for teachers should be communicated to teachers in advance and adjusted to their preferences which will allow participants to be involved,

- training and materials as well as catering during the training should be free of charge for participants which will minimize the costs of teachers' participation in training,

- participants should be recruited within homogeneous groups teaching similar subjects which will enable the exchange of experiences and improve the process of sharing practical knowledge among teachers,

- the methodology of classes should be based on a short introduction (lecture), individual or group exercises, using case studies and involving participants in discussions and exchanging good practices which will allow to refer to the experiences and knowledge of participants in accordance with the Kolb cycle (experience-reflection-generalizingapplication),

- didactic means and tools must be varied, the trainer should use a variety of media as much as possible (flipchart, multimedia presentation, interactive board and computer programmes) which will improve perception and activate participants,

- the trainer should establish very good rapport with participants, create a pleasant atmosphere, be an expert and authority in their field which will have a positive impact on teachers' perception of the content of education,

- the content of education should be adapted to the diagnosed needs of participants and the training should convey practical knowledge that can be applied in everyday professional work, encourage reflection and inspire further learning. 


\section{References}

1. Fazlagić, J. (2014). Jakość szkoleń nauczycieli z perspektywy wykładowców. Zarządzanie publiczne, 4(28).

2. Fila, J., Matuszczak, K., Rybińska, A. et al. (2015). Uwarunkowania i efekty wspomagania pracy szkół i przedszkoli. Raport z ewaluacji bieżącej projektów konkursowych Działania 3.5 POKL. Warszawa: Instytut Badań Edukacyjnych, www.ibe.edu.pl, 30.12.2019.

3. Fischer, J.M., Taylor, J. (2012). Wspieranie zespołów nauczycieli w procesie podejmowania decyzji. In: G. Mazurkiewicz (ed.), Jakość w edukacji: różnorodne perspektywy. Kraków: Wydawnictwo Uniwersytetu Jagiellońskiego.

4. Gocłowska, A., Soćko, J. (eds.) (2015). Jak samorząd może wspierać szkoły. Informacje o nowym systemie wspomagania. Warszawa: Ośrodek Rozwoju Edukacji.

5. Hajdukiewicz, M., Wysocka, J. (2016). Nauczyciel w szkole uczacej się. Informacje o nowym systemie wspomagania. Warszawa: Ośrodek Rozwoju Edukacji, 30.01.2019.

6. Hernik, K., Malinowska, K., Piwowarski, R. et al. (2014). Polscy nauczyciele i dyrektorzy na tle międzynarodowym. Główne wyniki badania TALIS 2013. Warszawa: Instytut Badań Edukacyjnych.

7. Kordziński, J. (2010). Koncepcja pracy i rozwoju szkoły. Praktyczne wskazówki dla dyrektorów placówek oświatowych. Warszawa: Wydawnictwo Verlag Dashofer Sp. z o.o.

8. Ministerstwo Edukacji Narodowej (2019). Model szkoły ćwiczeń. Załacznik $n r 11$ do Regulaminu konkursu, nr POWR.02.10.00-IP.02-00-003/19. Wsparcie tworzenia szkót ćwiczeń. II edycja, www.efs.men.gov.pl, 24.12.2019.

9. Ministerstwo Edukacji Narodowej (2019). Zasady współpracy szkoły ćwiczeń. Załacznik nr 15 do Regulaminu konkursu, nr POWR.02.10.00-IP.02-00-003/19. Wsparcie tworzenia szkót ćwiczeń, II edycja, www.efs.men.gov.pl, 24.12.2019.

10. Ministerstwo Rozwoju Regionalnego (2019). Szczegółowy Opis Osi Priorytetowych Programu Operacyjnego Wiedza Edukacja Rozwój 2014-2020, www.power.gov.pl, 30.12.2019.

11. Włudarczyk, A. (2010). Zawód: trener biznesu - czego firmy oczekują od dostawców usług szkoleniowo-doradczych. Szkolenia w Polsce 2010. Nowoczesna Firma, nr 10.

12. Wysocka, J., Hajdukiewicz, M. (2016). Zapewnianie jakości procesu wspomagania szkót w rozwoju. Warszawa: Ośrodek Rozwoju Edukacji, 30.12.2019. 